\title{
A Desire unto Death: The Warnings of Girard and Levinas against the Sanitisation of Euthanasia
}

\author{
Nigel Zimmermann
}

\section{Introduction}

In this chapter I make three propositions. First, a word on the nature of facing death; second, I propose that we have much to learn from the warnings of René Girard and Emmanuel Levinas against the false promise of euthanasia; third, we may view their warnings as a lesson for us facing the particular reality of voluntary assisted dying (VAD), what can be called a 'soft' version of euthanasia. VAD has been a reality in the State of Victoria since 19 June 2019 and other Australian jurisdictions are considering similar legislation. The Girard-Levinas critique of VAD issues us with a responsibility for those who suffer rather than the chilling prospect of a bureaucratic process of magnified autonomy resulting in the death of those most vulnerable to pressure and coercion. 


\section{Facing death}

In Victoria's VAD legislation, a sanitising promise is made to those who suffer: your pain will be lessened and your autonomy increased. While the Voluntary Assisted Dying Act 2017 (Vic) places bureaucratic restrictions upon those who can access VAD and under what circumstances, the promise is issued full of optimism about how a magnified individual autonomy can result in shared happiness among those involved in the exercise of desiring and enacting one's death. Campaigners for VAD suggest that the exercise of autonomy represents an overwhelmingly positive result for the happiness of Victoria residents, such as in a documentation of the process undertaken by the Ministerial Advisory Panel that ultimately drafted the legislation and made a case for its successful implementation. They advised:

This change represents a major shift in exercise of individual autonomy over that of the state. In tolerant communities, it is noted that acceptance of control over dying links to other personal freedom-in-life choices. ${ }^{1}$

These kinds of positive connotations pepper the description by Margaret O'Connor and others: notions of tolerance, personal control and autonomy, personal freedom and, of course, choice.

However, René Girard argues for the opposite; contrary to making the end of life positive or easier, euthanasia places a heavy burden of responsibility on each person for his or her own death, and will make death harder, more painful and ultimately a heavier burden at the end of life. Those with fewer resources - spiritual, material, familial and social - will be at greater risk of harm. This question of the responsibility to die has been passed over by the supporters of VAD because the way that social relationships of mutual and complementary responsibility operate is an inconvenient obstacle to arguments in favour of steps towards euthanasia. Girard's ethical concerns, and the analysis of alterity in Emmanuel Levinas, provides a chilling warning that death, and therefore life, has now become more burdensome for health providers, family and loved ones. Violence is a logical and usually unintended correlate.

1 Margaret M O'Connor et al, 'Documenting the Process of Developing the Victorian Voluntary Assisted Dying Legislation' (2018) 42(6) Australian Health Review 621. 
On 19 June 2019, a possibility opened up for patients who meet certain criteria to be able to embark on a complicated bureaucratic process to legally obtain access to a form of physician-assisted suicide, a 'soft' version of euthanasia, in the State of Victoria, under the Voluntary Assisted Dying Act 2017.2 After the Act passed Victoria's Houses of Parliament, the Premier referred to that moment as 'a day of reform, a day of compassion, a day of giving control to those who are terminally ill'. ${ }^{3}$

Similar proposals are being considered in other jurisdictions around the world and are much advanced in places like the Netherlands and Canada, and in ethically dubious and less monitored contexts in China and other parts of South-East Asia. Legislation based on Victoria's VAD model are increasingly probable in states like Queensland and Western Australia, given how public sentiment seems to be reflected, representing a push to force all of us to face questions of death and the treatment of those who are dying or in conditions of pain and anxiety with a new urgency and in a new situation.

In the time following the introduction of VAD the situation has not become less problematic. For example, a Voluntary Assisted Dying Review Board exists for the purposes of reporting to parliament every six months for the first two years of VAD, but it has not proven to be transparent in its own processes. In its report for the period JanuaryJune 2020 the Board utilised anonymous quotes from patients, family and doctors who had been involved with a VAD assessment or process. ${ }^{4}$ Some quotes are negative but most are overwhelmingly positive, referring to VAD as providing for a 'beautiful, peaceful death', a 'beautiful passing' and a supportive pharmacy team who were 'so kind and understanding'. Negative comments were all related to the bureaucratic processes that are built into the VAD process in Victoria, such as references to the length of time it can take or the inconvenience of paperwork, disappointment at a doctor not wishing to facilitate VAD and frustration at having trouble finding a doctor willing to do likewise. ${ }^{6}$ The implication is that there

\footnotetext{
2 Voluntary Assisted Dying Act 2017 (Vic).
}

3 Jean Edwards, 'Euthanasia: Victoria Becomes First Australian State to Legalise Voluntary Assisted Dying' ABC News (online, 29 November 2017) <https://www.abc.net.au/news/2017-11-29/ euthanasia-passes-parliament-in-victoria/9205472>.

4 Voluntary Assisted Dying Review Board, Safer Care Victoria, Review of Operations January-June 2020 (Report No 3, 31 August 2020).

5 Voluntary Assisted Dying Review Board (n 4) 10, 12.

6 Voluntary Assisted Dying Review Board (n 4) 2, 7, 10. 
are too many obstacles to assisted suicide and that it can take too long. Disappointingly the VAD Review Board, across its first three reports, failed to address any of the following: what proportion of VAD applicants undertook palliative care assessment before taking their lives in this way; how many doctors were actually involved in VAD; what supports and information were available to family and loved ones; and were mental health assessments conducted for patients seeking VAD? The document reads less like a sober and transparent report than it does an advertising brochure for assisted suicide.

We are not dealing simply with death, but a desire unto death.

First, a word on the title of this chapter. The term, 'a desire unto death' is taken from an article published in 2008 by Jason Wardley titled, 'A Desire Unto Death: The Deconstructive Thanatology of Jean-Luc Marion', in the Heythrop Journal. ${ }^{7}$ It is a play on the words of Soren Kierkegaard's 1849 work, A Sickness Unto Death, under his pseudonym Anti-Climacus. ${ }^{8}$ Kierkegaard's book is a powerful work of existential thought within a Western Christian context. It pioneered a way of philosophical reflection that foreshadowed the subjective turn of modern philosophy without simply turning in on itself in pure self-referentiality, and considered questions of religious conviction in their radical bareness, critiquing easy bourgeois attitudes and practices that operated under the guise of respectability and neoliberal material comfort. Kierkegaard's account of despair was both human and relatable, and he drew on the long biblical tradition of Original Sin as a way of giving meaning to what we would now call depression, and the anxious seeking after that which gives us pleasure amid false promises and securities.

Death is ever-near in the work of Kierkegaard, and Wardley took his cues from the Danish writer when studying the thought of Jean-Luc Marion, heavily influenced by Emmanuel Levinas. Wardley wrote that phenomenology, and the most interesting philosophy of late modernity, draws us towards the strangeness of the other - the incarnate and visible stranger before us - which under careful reflection can appear in the horizon of death, because it is strangeness that pulls us out of ourselves in such a way that enables us to better understand the human condition

7 Kenneth Jason Wardley, “A Desire Unto Death”: The Deconstructive Thanatology of Jean-Luc Marion' (2008) 49(1) The Heythrop Journal 79.

8 Soren Kierkegaard, The Sickness Unto Death: A Christian Psychological Exposition of Edification and Awakening by Anti-Climacus, tr Alastair Hannay (Penguin, 2004). 
in which we inhabit. Death places before us limits and the horizon of finitude, raising numerous questions about the life we live. For Wardley, we encounter in death a stranger that calls attention to ourselves, which is why questions of religious conviction, and of God, always hover so near to ethical questions around the end of life. Both the notion of limits and the subject of God can make us uncomfortable in a late modern, secular liberal democracy, but being uncomfortable can be an aid to the telling of truth. Wardley finds Jean-Luc Marion's phenomenology of death perplexing in this regard, and not without its difficulties, but ultimately he argues that a phenomenology of death unnerves us in our relationship to death, to God and to those who are dying. He writes:

The God of Marion's Christian revelation is the God whom noone can see without dying, a look that we desire unto death. ${ }^{\text {? }}$

In other words, the perplexing search for God, even at a non-theological level, meets its conclusion in the face of death, regardless of one's religious commitments.

In 2014 Jason Wardley published Praying to a French God: The Theology of Jean-Yves Lacoste. ${ }^{10}$ Jason passed away after his book was published, but days before he could have held it in his hands, facing the horizon of death of which he had written much. A young man, having faced a two-year battle with a malignant neoplasm upon his brain that was already forming malignant metastases at the time of its discovery and diagnosis, Jason's mental functioning had gone into serious decline, his good judgment becoming uneven, and his intellectual prowess becoming sporadic in the midst of physical deprivations; and as such Jason was forced to face death. He was my friend, and while he faced his death with a cheerful countenance, he also felt his own loss deeply, but at no time did he wish to sanitise its meaning, nor did he wish to avoid his sufferings for the sake of an early suicide. Jason never entertained such a thought, largely because he had learned from Lacoste and Marion that to do so is not actually to meet death, but to avoid its face and the lessons it teaches. That is not an argument in itself against euthanasia, but I learned much from Jason, in both his philosophical reflections on death, and the way that he faced it when it arrived. What it does, however, is remind us that dying is not

$9 \quad$ Wardley (n 7) 93.

10 Kenneth Jason Wardley, Praying to a French God: The Theology of Jean-Yves Lacoste (Routledge, 2016). 
merely a discrete moment in the course of life, a fragment at the end, or a prologue, but includes the whole process of facing one's own death as a continuum in development in the course of a human life.

\section{René Girard and the burdens of euthanasia}

The French literary theorist René Girard (1923-2015) is best known for developing his theory of mimetic desire, the drama by which narratives in Western history cast light on the way in which a community becomes a crowd, mimics particular behaviours and desires of others, and can become a mob, seeking to locate upon an individual, or a particular community, or a caste of persons, blame for some form of suffering. According to Girard, violence is exercised upon the scapegoat so that salvation in one form or another can be obtained for the community. He finds this in literature of all descriptions and genres, and views it as the fundamental story at the heart of biblical literature and of Christian faith. The Christ is that figure of perfect suffering, torn and bloody because of the judgment of the mob, and whose death is hurried with salvific promise.

Girard has often turned his work to contemporary problems of death and suffering, and argues that Western cultures have been progressing through a forgetfulness of the scapegoating narrative, and a propensity to tell ourselves we are building paradise, all the while casting blame upon vulnerable people at the edges of our cities and suburbia for any suffering we still endure. ${ }^{11}$ Inasmuch as we blame others, according to this approach, we eschew our own responsibility.

In an interview with James Williams, published in 2000, Girard was asked his thoughts on increased calls for euthanasia. He answered:

The experience of death is going to get more and more painful, contrary to what many people believe. The forthcoming euthanasia will make it more rather than less painful because it will put the emphasis on personal decision in a way which was blissfully alien

11 See Girard's books Violence and the Sacred, tr Patrick Gregory (Johns Hopkins University Press, 1st ed, 1977); The Scapegoat, tr Yvonne Freccero (Johns Hopkins University Press, 1986); and Oedipus Unbound: Selected Writings on Rivalry and Desire, ed Mark Rogin Anspach (Stanford University Press, 2004). 
to the whole problem of dying in former times. It will make death even more subjectively intolerable, for people will feel responsible for their own deaths and morally obligated to rid their relatives of their unwanted presence. Euthanasia will further intensify all the problems its advocates think it will solve. ${ }^{12}$

Girard identifies a change that takes place when euthanasia, even a soft version such as VAD, is made legal. Advocates argue that autonomy is the sovereign value, and only by it can compassion be realised in our care for those who experience serious and prolonged suffering. ${ }^{13}$ However, the values of a society in which euthanasia is legal and one in which euthanasia is illegal must necessarily be different, and for Girard such a change in the law also results in increased capacities for social pressure and expectations that people will not just be responsible for their own death, but irresponsible when not enacting it at the appropriate time. The moral obligation of which Girard speaks does not lighten the burden upon the elderly, the sick and the disabled; it shifts the burden onto their shoulders in an intense way, such that we add to their pain instead of decreasing it. While Premier Daniel Andrews and his health minister used the language of compassion to appeal to the people of Victoria, Girard's warning goes unheeded, allowing us to liaise dangerously with a sanitised view of euthanasia that paints over the threats to those most vulnerable, most under pressure and with the most to lose.

\section{Emmanuel Levinas and the demands of the Other}

Emmanuel Levinas (1906-1995) was a Lithuanian Jewish philosopher who migrated to Paris and adopted French culture with the fervour of the convert, was largely responsible for bringing the thought of Edmund Husserl (1859-1938) to France, and crafted a radical philosophy of alterity - otherness - in response to Martin Heidegger (1889-1976). For Levinas, ethics is first philosophy, and phenomenology opens a way of describing the overwhelming ethical demand in the face of the other

12 René Girard, 'Epilogue: The Anthropology of the Cross: A Conversation with René Girard' in James Williams (ed), The Girard Reader (The Crossroad Publishing Company, 2000) 262, 277.

13 Similar arguments have been made against the primacy or adequacy of 'autonomy', such as J David Velleman's essay 'Against the Right to Die' (1992) 17(6) The Journal of Medicine and Philosophy: A Forum for Bioethics and Philosophy of Medicine 665. Velleman makes his argument from a Kantian perspective, but it has resonances with Girard on this point. 
person, the Other, for our responsible care and attention towards them. This is most effective in the demand issued forth from those in particular vulnerability and need.

Levinas had a complicated relationship with his own religious tradition, and although he was a Jewish adherent in a strong intellectual sense, matters of faith were private to him and he was shy of public religion or indeed public political commitments. During World War II his wife and daughter were spared death (despite later deportation) through the protection of a Catholic cloister, for which Levinas expresses gratitude and a painful joy. ${ }^{14}$ He comments upon his development of a view, largely taken from Franz Rosenzweig (1886-1929), that in Christianity and Judaism can be found a common measure of the (ethical) kenosis of God, as well as the necessity that God demands an incarnate servant-hood to the weak, hungry and the oppressed. ${ }^{15}$ According to Levinas the ethical demand of the Other, including the dying and those in great suffering, arrives pre-philosophical reflection, naked of political intrigue and without a religious identity. We are responsible for the Other not despite philosophy, politics and religion, but without appeal or reliance upon those commitments. ${ }^{16}$

Coming from the Polish philosophical school of Thomistic thought in dialogue with Husserlian phenomenology, Karol Wojtyla, better known as John Paul II, wrote of Emmanuel Levinas in an essay 'The Defence of Every Life':

I cannot dwell here on contemporary thinkers, but I must mention at least one name - Emmanuel Levinas, who represents a particular school of contemporary personalism and of the philosophy of dialogue. Like Martin Buber and Franz Rosenzweig, he takes up the personalistic tradition of the Old Testament, where the relationship between the human 'I' and the divine, absolutely sovereign 'THOU' is so heavily emphasized.

God, who is the supreme legislator, forcefully enjoined on Sinai the commandment 'Thou shalt not kill,' as an absolute moral imperative. Levinas, who, like his co-religionists, deeply

14 Emmanuel Levinas and Jill Robbins, Is It Righteous to Be? Interviews with Emmanuel Levinas (Stanford University Press, 2001) 257.

15 Levinas (n 14) 256.

16 The use of other or Other can be a complicated business in commentary on Levinas. Here, I try to use the capitalised 'Other' when using the other person in the conceptual sense of Levinas, with its overwhelming connotations of difference and distance. I use the 'other' when simply referring to the other person in a more perfunctory or less abstract sense. 
experienced the tragedy of the Holocaust, offers a remarkable formulation of this fundamental commandment of the Decalogue - for him, the face reveals the person. This philosophy of the face is also found in the Old Testament: in the Psalms, and in the writings of the Prophets, there are frequent references to 'seeking God's face' (cf. Ps 26[27]:8). It is through his face that man speaks, and in particular, every man who has suffered a wrong speaks and says the words 'Do not kill me!' The human face and the commandment 'Do not kill' are ingeniously joined in Levinas, and thus become a testimony for our age, in which governments, even democratically elected governments, sanction executions with such ease.

Perhaps it is better to say no more than this about such a painful subject. ${ }^{17}$

John Paul's reading of Levinas weaves together the strangeness of the Other with the dark episodes of history, in which, including in the present, there are regimes that kill the Other, committing acts of violence that deny the unique significance of every human face, devoid of a moral awareness of what is being trampled upon and disfigured.

The Levinasian injunction of the face is an interruption of both personal comfort and any attempt to view our relation to other persons in an ethically sanitised manner. It is not merely an invitation but a demand, and in a peculiar kind of way the Victorian Government has forced us to look at the face of the other with a new intensity, while at the same time legislating for their death.

Levinas's work has been described as the 'phenomenology of alterity'. ${ }^{18}$ This is in evidence from his earliest works. In the early 1930s, Levinas became the French translator of Husserl's Cartesian Meditations, thus forging an important bridge between German phenomenology and its French descendants that blossomed in Paris throughout the latter part of the twentieth century. ${ }^{19}$ This translation was followed by The Theory of Intuition in Husserl. ${ }^{20}$ Nevertheless, it was not until Totality and Infinity was published in 1961 that his original contribution to phenomenology

17 John Paul II, Crossing the Threshold of Hope, ed Vittorio Messori, tr Jenny McPhee and Martha McPhee (Jonathan Cape, 1994) 210-11 (emphasis in the original).

18 Dermot Moran, Introduction to Phenomenology (Routledge, 2000) 320.

19 Moran (n 18) 320.

20 La théorie de l'intuition dans la phénoménologie de Husserl (1930): Emmanuel Levinas, The Theory of Intuition in Husserl's Phenomenology, tr Andre Orianne (Northwestern University Press, 2nd ed, 1995). 
was made manifest. ${ }^{21}$ In that book he introduces a radicalised appreciation of alterity in terms of ethics, contra Heidegger, for whom ethics was not a branch of fundamental ontology. ${ }^{22}$ This was developed further with Otherwise than Being or Beyond Essence, in the declaration that Western philosophy has, at heart, treated difference and the other with disdain by giving primary significance to being as the fundamental category. ${ }^{23}$ Levinas's idea was not a rejection of being per se, but rather understanding it 'on the basis of being's other'. ${ }^{24}$ Unlike Wojtyla, for whom metaphysics in the tradition of Aristotle and Thomas provides a necessary corrective to the limitations of phenomenology, Levinas draws on Plato as a self-inversion of the Western philosophical tradition. ${ }^{25}$ For him, Plato's prioritisation of the good beyond being challenges the prioritisation of ontology, so reinterpreting the whole philosophical tradition from Plato onwards. Levinas insists that the going out of the self for the sake of the other absolute responsibility - places the self in the role of 'hostage', restless and 'gnawing away at oneself', both 'inspired' and taken up completely in one's psyche for the sake of the good of the other. ${ }^{26}$ The body of the other is taken up into the self's own ethical practice, just as it is infinitely distant. Levinas says:

The psyche can signify this alterity in the same without alienation in the form of incarnation, as being-in-one's-skin, having-theother-in-one's-skin. ${ }^{27}$

21 Emmanuel Levinas, Totality and Infinity: An Essay on Exteriority, tr Alphonso Lingis (Duquesne University Press, 1969).

22 Throughout Sein und Zeit (1927), Heidegger is concerned with the nature of authenticity and does not develop an ethics as such, nor clearly describe the role ethics might play in his philosophy. See Martin Heidegger, Being and Time, tr John Macquarrie and Edward Robinson (SCM Press, 1962). The Levinasian critique has been contested by Heidegger interpreters such as Laurence Paul Hemming who rejects Levinas' argument that Being and Time instrumentalises the other for the sake of the self. See Laurence Paul Hemming, 'A Transcendental Hangover: Lévinas, Heidegger and the Ethics of Alterity' (2005) 18(2) Studies in Christian Ethics 45.

23 Autrement qu'être ou au-delà de l'essence (1978): Emmanuel Levinas, Otherwise Than Being: Or Beyond Essence, tr Alphonso Lingis (Duquesne University Press, 1998).

24 Levinas (n 23) 16.

25 See for example, Sarah Allen, The Philosophical Sense of Transcendence: Levinas and Plato on Loving Beyond Being (Duquesne University Press, 2009); Tanja Staehler, Plato and Levinas: The Ambiguous Out-Side of Ethics (Routledge, 2010); Mary-Ann Webb, 'Eros and Ethics: Levinas's Reading of Plato's "Good Beyond Being"' (2006) 19(2) Studies in Christian Ethics 205.

26 Levinas (n 23) 114.

27 Levinas (n 23) 114-15. 
Here, Levinas makes use of his phrase 'the same' as denoting that which is not just the self, but all that lies close to the self; that which we associate with ourselves in some intimate and comfortable sense. According to Levinas, the psyche has a capacity to enfold within itself difference at the same time as sameness, a complicated event that is never stable and always undergoing a paradoxical challenge from the Other. The key is that even when enfolded in an unclear and ambiguous relationship, the Other holds the self to account and maintains a relationship of utter responsibility towards that which is different. Such a relationship is both beyond and prior to all our professional relationships, including that of the doctor and the patient.

The God of the Hebrews marked an unambiguous ethical boundary: 'Thou shalt not kill'. For Levinas the command is not only a verbal or literary command; it is inscribed in the humanity of the other person: do not kill me. Such a demand derives from the experience of human community in which difference is honoured and respected, regardless of whether one believes the command is uttered by the Creator or not.

For Marion, what Levinas draws our attention to, past the loud voice of the state or of personal investment or the incursions of bureaucracy, is the ethical 'call' or even better, the 'appeal'. ${ }^{28}$ In the appeal of the face, we are addressed in a singular demand. One receives the address as a demanding excess of meaning in which both a summons and a command are issued without hesitation. Marion takes this up in his phenomenological analysis of what he describes as 'saturated phenomena' (the event, the idol, flesh and the icon). ${ }^{29}$ The call and the appeal, which is received in a presence that exceeds all understanding and containment, which 'saturates' one's intentionality, relies very much on the notion of an event that speaks personally to us. Levinas's critique of Western philosophy and its compulsion to circumvent all thought into Being, and the ethical signification of alterity in the face of the Other, create the means by which human nature can speak to us and call us away from easy answers designed to release us from simple questions. The otherness of the Other, who is thought beyond Being, is present in a way that so saturates one's ethical relationship with its subjective constitution that

28 See Jean-Luc Marion, 'The Final Appeal of the Subject', in John D Caputo (ed), The Religious (Blackwell, 2002); also Marion, The Erotic Phenomenon, tr Stephen E Lewis (University of Chicago Press, 2007).

29 See especially Jean-Luc Marion, In Excess: Studies of Saturated Phenomena, tr Robyn Horner and Vincent Berraud (Fordham University Press, 2002). 
it, in effect, envelopes and overcomes oneself. This effectively denies the possibility of reducing the Other in any way, even if in practical terms the Other may be diminished in its phenomenal experience. At the bedside of the dying, Levinas says we have to listen and watch more intensely, and this will mean that we must sometimes answer on behalf of the Other in their vulnerability, issuing a demand for better care, for more resources, for an investment of attention and even of love and friendship, and to mark a line in the sand so that our ethical commitments are not trampled through the soothing and sanitising language of a false compassion.

The appearing of another person in this way is the event of concrete human experience. It must not be interpreted as a mystical experience in any overtly religious sense, but as the ethical content that rises in the subjectivity of the most urbane human encounters. It is a radicalisation of human sociality. Marion takes this human moment - seemingly banal in its domestic sensibility - and interprets it to allow for the possibility of revelation. As Robyn Horner describes, revelation can have a content, although as an excessive content it is marked as holding an inevitably hermeneutical supplement to phenomenology'. ${ }^{30}$ In other words, the excess has a boundary experience in which interpretation is necessitated.

For Levinas, death is the circumstance in which ethical action is possible. This is so because death makes us intrinsically vulnerable creatures, and so ethics has a very serious life-threatening gravity to it. A readiness to die for the Other proves the sincere disinterest of the ethical gesture, thus precluding the will to power. Levinas also assumes that we become self-aware and aware of other people through the cry of the vulnerable and the consequence that one must sacrifice oneself to meet the need indicated by that cry. The Other therefore is greater than us and places the demand for ethical attention upon us; it is not derived from our own natural disposition or commitments. It carries an objectivity that, for Levinas, has to remain absolute because our humanity demands it, and the command not to kill is unalterable. 


\title{
For or against the other? Against the sanitisation of euthanasia
}

In January 2019, The Guardian, whose editors have advocated for euthanasia, ran a story on how doctors are critically pushing back on physician-assisted suicide. ${ }^{31}$ Christopher de Bellaigue identifies two factors that are complicating the legal situation for euthanasia in Belgium, where it has been legal since 2002: autonomy and dementia. At least one euthanasia malpractice case is now in process in a situation in which a dementia patient's advance directive, which had instructed euthanasia to be administered in certain circumstances, has been called into question because of the changed mental state of the patient once they had an advanced form of dementia. Dementia is an uneven and complicated process and its advent does not necessarily mean that 'unbearable suffering' is being experienced. As Bellaigue explains:

\begin{abstract}
The underlying problem with the advance directives is that they imply the subordination of an irrational human being to their rational former self, essentially splitting a single person into two mutually opposed ones. Many doctors, having watched patients adapt to circumstances they had once expected to find intolerable, doubt whether anyone can accurately predict what they will want after their condition worsens. ${ }^{32}$
\end{abstract}

Even if one argues that euthanasia adequately respects personal autonomy and is a means for showing genuine compassion for the other, who exactly can be said to have sovereignty over their own healthcare - the earlier rational self or the later self who is experiencing dementia? In the case of dementia, it is not always clear that the patient experiences the condition as a form of suffering per se. This helps to explain why review boards in Holland are finding it more difficult to reach consensus on particular requests for euthanasia, and a tension between increased societal pressure to keep euthanasia available on the principle of autonomy, and expectations of thoughtful ethical deliberation for those called to make the final decision. We have here an example of Girard's prediction about the new expectations to conform to the pressures of a legal-euthanasia

31 Christopher de Bellaigue, 'Death on Demand: Has Euthanasia Gone Too Far?' The Guardian (online, 18 January 2019) <https://www.theguardian.com/news/2019/jan/18/death-on-demand-haseuthanasia-gone-too-far-netherlands-assisted-dying $>$.

32 Bellaigue (n 31). 
context. Doctors are pushing back on such pressures, and showing signs of resentment for the expectation that they are simply there to sign off on every such request. Those advocating for increased liberalisation of euthanasia often represent interests more aligned to neoliberal principles of autonomy and material gain, as Bellaigue observes:

At any meeting organised by the NVVE [Dutch Voluntary Euthanasia Society], you will look in vain for poor people, pious Christians or members of the Netherlands' sizeable Muslim minority. Borne along by the ultra-rational spirit of Dutch libertarianism (the spirit that made the Netherlands a pioneer in reforming laws on drugs, sex and pornography), the Dutch euthanasia scene also exudes a strong whiff of upper-middle class entitlement. $^{33}$

It is no wonder that pressures around euthanasia as an entitlement have become pronounced as baby boomers reach the end of their lives; the generation that won the battle for access to contraception, pornography and abortion as teens and young adults, are the same who now wish to exercise control over their death. However, like contraception and abortion, the long-term implications are never known in the immediate aftermath of a new change in legislation, but only after a generation or two have lived with that change of values. While the Netherlands and other jurisdictions are just beginning to give us a glimpse of the results of euthanasia, we are still a long way to go from having a full picture, but at the very least we should avoid sanitised narratives about the good that euthanasia or VAD will achieve, and be more attentive to others in their suffering, without the loud voices of campaigners shouting us down.

\section{Conclusion}

The call of the Other in Levinas, and the grim predictions of Girard, constitute a warning for us in jurisdictions in which euthanasia, even along the lines of 'voluntary assisted' dying in Victoria, is being liberalised and endorsed. There is a seduction in the language of compassion and the cessation of suffering, even if it is ill-informed, and it can hide a sinister denial of the vulnerability and fragility of the Other, especially given the complexities of mental and physical decline. We have opened ourselves

33 Bellaigue (n 31). 
up not to a magnification of autonomy, but increased pressures to be responsible for one's own death to not be a burden, and to suppress intense fears and anxieties that are better worked out in dialogue and friendship. As Girard puts it:

The increasing subjective power of death converges with the fact that people are living longer lives. It is an enormous religious and ethical issue, to my mind. In the Netherlands, where I gather assisted suicides have become commonplace, there are claims that some of the assisted suicides are not suicides at all. Even if they are, the suspicion will linger that they are not, and the fear of being murdered is going to merge once again with the fear of dying. Our supermodern utopia looks very much at times like a regression to archaic terror. ${ }^{34}$

\section{Bibliography}

\section{A Articles/books/reports}

Allen, Sarah, The Philosophical Sense of Transcendence: Levinas and Plato on Loving Beyond Being (Duquesne University Press, 2009)

Girard, René, 'Epilogue: The Anthropology of the Cross: A Conversation with René Girard' in James Williams (ed), The Girard Reader (The Crossroad Publishing Company, 2000) 262

Girard, René, Oedipus Unbound: Selected Writings on Rivalry and Desire, ed Mark Rogin Anspach (Stanford University Press, 2004)

Girard, René, The Scapegoat, tr Yvonne Freccero (Johns Hopkins University Press, 1986)

Girard, René, Violence and the Sacred, tr Patrick Gregory (Johns Hopkins University Press, 1st ed, 1977)

Hart, David Bentley, The Beauty of the Infinite: The Aesthetics of Christian Truth (Eerdmans, 2003)

Heidegger, Martin, Being and Time, tr John Macquarrie and Edward Robinson (SCM Press, 1962) 
Hemming, Laurence Paul, 'A Transcendental Hangover: Lévinas, Heidegger and the Ethics of Alterity' (2005) 18(2) Studies in Christian Ethics 45 doi.org/ $10.1177 / 0953946805054804$

Horner, Robyn, Jean-Luc Marion: A Theo-Logical Introduction (Routledge, 2005)

John Paul II, Crossing the Threshold of Hope, ed Vittorio Messori, tr Jenny McPhee and Martha McPhee (Jonathan Cape, 1994)

Kierkegaard, Soren, The Sickness Unto Death: A Christian Psychological Exposition of Edification and Awakening by Anti-Climacus, tr Alastair Hannay (Penguin, 2004)

Levinas, Emmanuel, Otherwise than Being, or Beyond Essence, tr Alphonso Lingis (Duquesne University Press, 1998)

Levinas, Emmanuel, The Theory of Intuition in Husserl's Phenomenology, tr Andre Orianne (Northwestern University Press, 2nd ed, 1995)

Levinas, Emmanuel, Totality and Infinity: An Essay on Exteriority, tr Alphonso Lingis (Duquesne University Press, 1969)

Levinas, Emmanuel and Jill Robbins, Is It Righteous to Be? Interviews with Emmanuel Levinas (Stanford University Press, 2001)

Marion, Jean-Luc, In Excess: Studies of Saturated Phenomena, tr Robyn Horner and Vincent Berraud (Fordham University Press, 2002)

Marion, Jean-Luc, The Erotic Phenomenon, tr Stephen E Lewis (University of Chicago Press, 2007)

Marion, Jean-Luc, 'The Final Appeal of the Subject' in John D Caputo (ed), The Religious (Blackwell, 2002)

Milbank, John, 'The Ethics of Self-Sacrifice' [1999] (91) First Things: A Monthly Journal of Religion \& Public Life 33

Moran, Dermot, Introduction to Phenomenology (Routledge, 2000)

O'Connor, Margaret $\mathrm{M}$ et al, 'Documenting the Process of Developing the Victorian Voluntary Assisted Dying Legislation' (2018) 42(6) Australian Health Review 621 doi.org/10.1071/AH18172

Staehler, Tanja, Plato and Levinas: The Ambiguous Out-Side of Ethics (Routledge, 2010) 
Velleman, J David, 'Against the Right to Die' (1992) 17(6) The Journal of Medicine and Philosophy: A Forum for Bioethics and Philosophy of Medicine 665 doi.org/10.1093/jmp/17.6.665

Voluntary Assisted Dying Review Board, Safer Care Victoria, Report of Operations January-June 2020 (Report No 3, 31 August 2020)

Wardley, Kenneth Jason, “A Desire Unto Death": The Deconstructive Thanatology of Jean-Luc Marion' (2008) 49(1) The Heythrop Journal 79 doi.org/10.1111/j.1468-2265.2007.00358.x

Wardley, Kenneth Jason, Praying to a French God: The Theology of Jean-Yves Lacoste (Routledge, 2016)

Webb, Mary-Ann, 'Eros and Ethics: Levinas's Reading of Plato's "Good Beyond Being"' (2006) 19(2) Studies in Christian Ethics 205 doi.org/10.1177/ 0953946806066151

\section{B Legislation}

Voluntary Assisted Dying Act 2017 (Vic)

\section{Other}

Bellaigue, Christopher de, 'Death on Demand: Has Euthanasia Gone Too Far?', The Guardian (online, 18 January 2019) <http://www.theguardian. $\mathrm{com} /$ news/2019/jan/18/death-on-demand-has-euthanasia-gone-too-farnetherlands-assisted-dying>

Edwards, Jean, 'Euthanasia: Victoria Becomes the First Australian State to Legalise Voluntary Assisted Dying', ABC News (online, 29 November 2017) <https:/www.abc.net.au/news/2017-11-29/euthanasia-passes-parliamentin-victoria/9205472> 
This text is taken from Voluntary Assisted Dying: Law? Health? Justice?, edited by Daniel J Fleming and David J Carter, published 2022 by ANU Press, The Australian National University, Canberra, Australia.

doi.org/10.22459/VAD.2022.07 